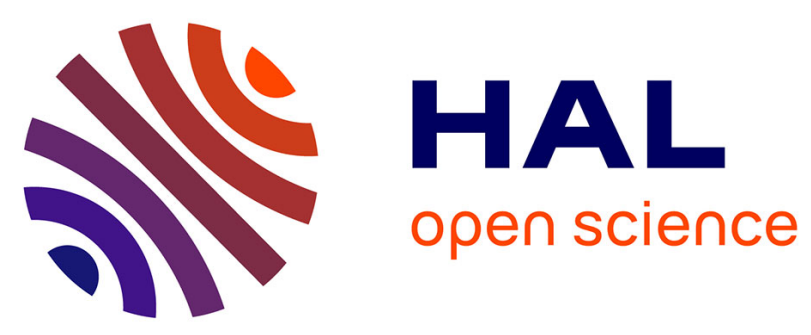

\title{
Effects of patulin and ascladiol on porcine intestinal mucosa: An ex vivo approach
}

Leila Maidana, Juliana R. Gerez, Rhoda El Khoury, Felipe Pinho, Olivier

Puel, Isabelle P. Oswald, Ana-Paula Loureiro-Bracarense

\section{To cite this version:}

Leila Maidana, Juliana R. Gerez, Rhoda El Khoury, Felipe Pinho, Olivier Puel, et al.. Effects of patulin and ascladiol on porcine intestinal mucosa: An ex vivo approach. Food and Chemical Toxicology, 2016, 98, pp.189-194. 10.1016/j.fct.2016.10.001 . hal-01451293

\section{HAL Id: hal-01451293 \\ https://hal.science/hal-01451293}

Submitted on 1 Oct 2017

HAL is a multi-disciplinary open access archive for the deposit and dissemination of scientific research documents, whether they are published or not. The documents may come from teaching and research institutions in France or abroad, or from public or private research centers.
L'archive ouverte pluridisciplinaire HAL, est destinée au dépôt et à la diffusion de documents scientifiques de niveau recherche, publiés ou non, émanant des établissements d'enseignement et de recherche français ou étrangers, des laboratoires publics ou privés. 


\section{Accepted Manuscript}

Effects of patulin and ascladiol on porcine intestinal mucosa: An ex vivo approach

Leila Maidana, Juliana R. Gerez, Rhoda El Khoury, Felipe Pinho, Olivier Puel, Isabelle P. Oswald, Ana Paula F.R.L. Bracarense

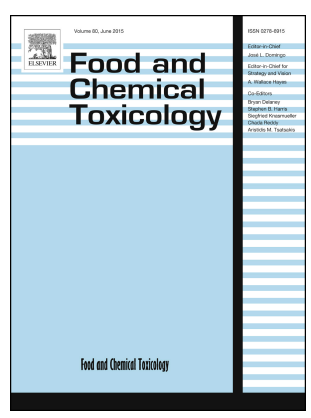

PII:

S0278-6915(16)30351-9

DOI:

10.1016/j.fct.2016.10.001

Reference: $\quad$ FCT 8742

To appear in: Food and Chemical Toxicology

Received Date: 5 July 2016

Revised Date: 14 September 2016

Accepted Date: 1 October 2016

Please cite this article as: Maidana, L., Gerez, J.R., El Khoury, R., Pinho, F., Puel, O., Oswald, I.P., Bracarense, A.P.F.R.L., Effects of patulin and ascladiol on porcine intestinal mucosa: An ex vivo approach, Food and Chemical Toxicology (2016), doi: 10.1016/j.fct.2016.10.001.

This is a PDF file of an unedited manuscript that has been accepted for publication. As a service to our customers we are providing this early version of the manuscript. The manuscript will undergo copyediting, typesetting, and review of the resulting proof before it is published in its final form. Please note that during the production process errors may be discovered which could affect the content, and all legal disclaimers that apply to the journal pertain. 
Effects of patulin and ascladiol on porcine intestinal mucosa: an ex vivo approach

Leila Maidana a, Juliana R. Gerez ${ }^{\text {a }}$, Rhoda El Khoury ${ }^{\text {bc }}$, Felipe Pinho ${ }^{\text {a }}$, Olivier Puel ${ }^{\text {b }}$, Isabelle P. Oswald ${ }^{\text {b }}$, Ana Paula F.R.L. Bracarense ${ }^{\text {a,* }}$

${ }^{a}$ Universidade Estadual de Londrina, Laboratory of Animal Pathology, Campus Universitário, Rodovia Celso Garcia Cid, Km 380, Londrina, Paraná 86051-990, Brasil.

${ }^{\mathrm{b}}$ Université de Toulouse, Toxalim (Research Center in Food Toxicology), INRA, ENVT, INP-PURPAN, UPS, Toulouse, France.

${ }^{\mathrm{c}}$ Université Saint-Joseph, Centre d'Analyses et de Recherches (Faculté des Sciences), Campus des Sciences et Technologies, Mar Roukos, Mkallès, P.O Box 11- 514 Riad El Solh, Beyrouth 1107 2050, Lebanon.

*Corresponding author: Ana Paula F.R.L. Bracarense

e-mail address: ana.bracarense @pq.cnpq.br

Telephone: 554333714485

Fax: 554333714485 


\section{Abstract}

Patulin (PAT) is a secondary metabolite mainly produced by Aspergillus and Penicillium that is frequently found contaminating apples and rotten fruits. Patulin can be transformed in potencially less toxic compounds such as ascladiol (ASC). Toxic effects of patulin were described in rats and in in vitro models, however concerning ascladiol, data are restricted to metabolic pathways. The aim of the present study was to evaluate the effects of different concentrations of PAT $(10 \mu \mathrm{M}, 30 \mu \mathrm{M}, 100 \mu \mathrm{M})$ and ASC $(30 \mu \mathrm{M}, 100 \mu \mathrm{M})$ on intestinal tissue using the jejunal explant model. Explants from pigs were exposed for 4 hours to PAT and ASC and after this period were processed for histological, morphometrical and immunohistochemical analysis. Mild histological changes were observed in jejunal explants exposed to PAT and ASC, however no significant difference in the lesional score or villi height was observed between the PAT/ASC-groups and the control. Also, explants exposed to $100 \mu \mathrm{M}$ of PAT showed a significant decrease in goblet cells density and a significant increase in cell apoptosis. These results indicate that high levels of patulin can induce mild toxic effects on intestinal mucosa whereas ascladiol apparently is non-toxic to intestinal tissue.

Keywords: intestinal explants, mycotoxins, goblet cells, histopathology, toxicity. 


\section{Introduction}

Mycotoxins are secondary fungal metabolites and are found as food contaminants with harmful impact on human and animal health. Their occurrence in commercialized food and feed is a consequence of fungal attacks on crops in the field and/or on stored products (Ferrer et al., 2015; Ianiri et al., 2016).

Patulin (PAT) is a polyketide mycotoxin mainly produced by Aspergillus, Penicillium and Byssochlamys (Mohan et al., 2012). It is a frequently found contaminant in spoiled fruits, especially apples and related products (Beretta et al., 2000; Puel et al., 2010; Yang et al., 2014), but also described in vegetables products (Lugauskas et al., 2005), stored cheese and cereal products (Lopez-Diaz et al., 1996; Lopez-Diaz and Flannigan, 1997). This mycotoxin is easily transferred into the products during the processing owing to its solubility in water and stability to heat in acidic medium (Raiola et al., 2012).

The World Health Organization (WHO) established a safety level of $50 \mu \mathrm{g} / \mathrm{L}(0.32 \mu \mathrm{M})$ for apple juice (Food and Agriculture Organization of the United Nations/WHO, 2003) which was taken over by many European Union countries and the United States (Commission of the European Communities, 2006; Glaser and Stopper, 2012). The maximum permitted levels of PAT have been set at $50 \mu \mathrm{g} / \mathrm{kg}$ for apple based products, 25 $\mu \mathrm{g} / \mathrm{kg}$ for solid apple products and maximum level of $10 \mu \mathrm{g} / \mathrm{kg}$ for all products intended for infants and young children (Appell et al., 2009; Hawar et al., 2013). Patulin levels in apple juices range from 0.7 to $845 \mu \mathrm{g} / \mathrm{L}$ worldwide (Oroian et al., 2014; Rahimi and Rezapoor Jeiran, 2015; Saxena et al., 2008), however levels until 16,402 and 44,572 $\mu \mathrm{g} / \mathrm{kg}$ were reported in conventional and organic fresh apples, respectively (Piemontese et al., 2005). 
In vivo studies have indicated that acute ingestion of PAT $(48 \mathrm{mg} / \mathrm{kg})$ induces toxic effects to the gastrointestinal tract of rats, including mucosal ulceration and inflammation (McKinley and Carlton, 1980). Mice submitted to an ingestion of $152.5 \mu \mathrm{g} / \mathrm{kg}$ of PAT for six weeks showed liver necrosis, glomerular degeneration and neurotoxicological effects (Al-Hazmi, 2014). Additionally, intestinal cell lines (HT-29-D4 and Caco-2-14) exposed to PAT (15 to $100 \mu \mathrm{M}$ ) showed a significant decrease of transepithelial resistance (TER) without major signs of toxicity (Mahfoud et al., 2002). On the other hand, toxic effects were reported in kidney cell lines (Riley and Showker, 1991; Pillay et al., 2015), chinese hamster ovary cell line (CHO-K1) (Ferrer et al., 2009) and human promyelocytic leukaemia (HL-60) cells (Liu et al., 2007) exposed to 0.1 to $100 \mu \mathrm{M}$ of PAT.

The toxic effects that PAT exerts on cells may be due to its electrophilic nature, reacting with sulphydryl moieties, and cross linking proteins and peptides (Ciegler et al., 1976; Mohan et al., 2012) including covalent inactivation of anti-oxidants (Fliege and Metzler, 2000). This way, PAT induces oxidative stress by lowering the concentration of the antioxidant peptide glutathione, and through generation of reactive oxygen species (ROS) (Barhoumi and Burghardt, 1996). ROS generation plays a role in the molecular events leading to apoptotic processes particularly by inducing peroxidation of membrane lipids and oxidative DNA damage (Ferrer et al., 2009; Zhou et al., 2009; De Melo et al., 2012). There is increasing evidence supporting a role for apoptosis in the toxicity of PAT (Saxena et al., 2009; De Melo et al., 2012; Kwon et al., 2012).

Patulin can be transformed in potencially less toxic compounds such as ascladiol (ASC) and desoxypatulinic acid. Previous studies using Saccharomyces cerevisiae (Suzuki and Iwahashi, 2011; Shao et al., 2012), Rhodosporidium kratochvilovae (Castoria et al., 2011) 
and Gluconobacter oxydans (Ricelli et al., 2007) showed that these microorganisms are able to reduce PAT levels by a biotransformation process. There is an increasing interest in the use of yeasts as a biocontrol alternative to reduce or avoid patulin production in fruits, especially apples. Nevertheless, toxicological information about the resulting metabolites is scarce (Suzuki et al. 1971; Tannous et al. 2016).

Over the years, in vivo models were conducted to evaluate systemic effects of patulin (Speijers et al., 1988; Gc et al., 1998; Saxena et al., 2009; De Melo et al., 2012) and in vitro models reported individual cellular response to this mycotoxin (Schumacher et al., 2005; Zhou et al., 2009; Glaser and Stopper, 2012), but no ex vivo model was performed to achieve toxicological effects of PAT or ASC on intestinal mucosa. Moreover, histological aspects were rarely focused in these previous reports. In the context of further studies in intestinal toxicity induced by PAT and ASC, this report aimed to evaluate the effects of different concentrations of patulin and its metabolite ascladiol on porcine jejunal explants. To assay this, we performed histological, immunohistochemical and morphometrical analysis on intestinal tissue using an ex vivo model. Intestinal explants from pigs allow preservation of the normal histological structure (Basso et al., 2013) and represent a less costly model.

\section{Materials and Methods}

\subsection{Animals}

For explants sampling, six male 4-5 week-old crossbred piglets were used, housed in the animal facility of the INRA ToxAlim Laboratory (Toulouse, France). The experimental procedures were conducted in accordance with European Guidelines for the Care and Use 
of Animals for Research Purposes and were approved by the INRA local ethical committees for animal experimentation (C3155513).

\subsection{Patulin and Ascladiol}

Patulin standard was acquired from Sigma-Aldrich (Saint Quentin Fallavier, France). The E-ascladiol standard used in this study was obtained by chemical synthesis as previously described (Shao et al., 2012; Tannous et al., 2016). Mycotoxins were dissolved in dimethyl sulfoxide (DMSO) (Sigma-Aldrich) and stored at $-20{ }^{\circ} \mathrm{C}$ until use. Patulin was dissolved to a final concentration of $10 \mu \mathrm{M}, 30 \mu \mathrm{M}$ and $100 \mu \mathrm{M}$ and ascladiol to $30 \mu \mathrm{M}$ and $100 \mu \mathrm{M}$.

\subsection{Jejunum explants culture}

The animals were used to obtain explants of jejunal tissue and the procedures for the culture of explants were performed as previously described (Kolf-Clauw et al., 2009). Fragments of $5 \mathrm{~cm}$ of medial jejunum were sampled immediately after euthanasia, and washed with buffered saline solution (PBS) and opened longitudinally. Explants were incubated for $4 \mathrm{~h}$ in Dulbecco's modified Eagle medium enriched with glutamine (Gibco, Cergy-Pontoise, France), supplemented with $10 \%$ heat-inactivated fetal bovine serum, $1 \%$ nonessential amino acids (Sigma-Aldrich) and 0.5\% gentamicin (Eurobio, Courtaboeuf, France) at $37^{\circ} \mathrm{C}$ under a $\mathrm{CO}_{2}$-controlled atmosphere with orbital shaking.

\subsection{Explants exposure to patulin and ascladiol}

The explants were deposited with the mucosa facing upwards (2 explants/well) and incubated at $37^{\circ} \mathrm{C}$ for 4 hours in the presence of PAT at $10 \mu \mathrm{M}, 30 \mu \mathrm{M}$ and $100 \mu \mathrm{M}$ and ASC at $30 \mu \mathrm{M}$ and $100 \mu \mathrm{M}$. 


\subsection{Histological and morphometric analysis}

After the incubation period, explants were fixed in $10 \%$ buffered formalin solution, dehydrated in increasing alcohols and embedded in paraffin for histological analysis. Explants were sectioned of $5 \mu \mathrm{m}$ thicknesses parallel to the villi axis, stained with hematoxylin and eosin (HE) or periodic acid of Schiff (PAS), and mounted with coverslips. The histological changes were evaluated using an adapted tissue score based on the intensity and severity of lesions as previously described (Cheat et al., 2015). The maximum score (39) indicates the overall integrity of the intestine. The criteria included in tissue score were number of villi, villi atrophy, villi fusion, cellular necrosis, presence of cellular debris, interstitial edema and morphology of enterocytes. The lesional score was calculated by taking into account the degree of severity (severity factor) and the extent of each lesion (according to intensity or observed frequency (scored from 0 to 3) (Table 1). Villi height was measured as the distance between the crypt mouth and the top of the villi randomly on 10 villi using the Motic Image Plus 2.0 software (Motic Instruments, Richmond, Canada).

\subsection{Goblet cells assessment}

Goblet cells density was performed separately throughout villus and crypt axis in histological sections of jejunal explants stained with PAS. Positively stained goblet cells were counted randomly in five fields per slide at 40x magnification, and the means were subjected to statistical analysis. 
Table 1. Criteria used to establish the lesional score - endpoints used and severity factors.

\begin{tabular}{|c|c|c|c|}
\hline & Criteria (severity factor) & End-point & Score \\
\hline \multirow{12}{*}{ 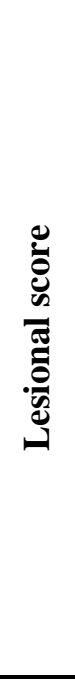 } & \multirow{4}{*}{ Enterocyte morphology (2) } & Columnar epithelium & 3 \\
\hline & & $<50 \%$ cuboidal epithelium & $2 C$ \\
\hline & & $>50 \%$ cuboidal epithelium & 1 \\
\hline & & Flattened epithelium & 0 \\
\hline & \multirow{4}{*}{ Apical denudation of villi (3) } & $0-11 \%$ & 3 \\
\hline & & $12-40 \%$ & 2 \\
\hline & & $41-70 \%$ & 1 \\
\hline & & $71-100 \%$ & 0 \\
\hline & \multirow{4}{*}{ Lesions of lamina propria (1) } & Absent & 3 \\
\hline & & Localized $<30 \%$ & 2 \\
\hline & & Multifocal $>31 \%$ & 1 \\
\hline & & Diffuse & 0 \\
\hline \multirow{16}{*}{ 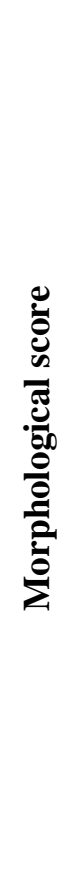 } & \multirow{4}{*}{ Villi fusion (2) } & $0-11 \%$ & 3 \\
\hline & & $12-40 \%$ & 2 \\
\hline & & $41-70 \%$ & 1 \\
\hline & & $71-100 \%$ & 0 \\
\hline & \multirow{4}{*}{ Number of villi (2) } & $>30$ & 3 \\
\hline & & 20-29 & 2 \\
\hline & & $10-19$ & 1 \\
\hline & & $<10$ & 0 \\
\hline & \multirow{4}{*}{ Villi atrophy (2) } & $0-11 \%$ & 3 \\
\hline & & $12-40 \%$ & 2 \\
\hline & & $41-70 \%$ & 1 \\
\hline & & $71-100 \%$ & 0 \\
\hline & \multirow{4}{*}{ Debris } & Absent & 3 \\
\hline & & Localized $<30 \%$ & 2 \\
\hline & & Multifocal $>31 \%$ & 1 \\
\hline & & Diffuse & 0 \\
\hline
\end{tabular}

\subsection{Apoptosis assessment}

Evaluation of apoptosis was performed on jejunal explants using antibody anti-cleaved caspase-3 (CCasp3) (clone Asp 175, 1:200 dilution, Cell Signaling Technology, Beverly, 
MA). The immunohistochemical procedures were performed as described previously (Silva et al., 2014). The immunoexpression of CCasp3 in jejunal explants was estimated by counting strongly positive immunostaining of cell cytoplasm in 500 epithelial cells at 400x magnification. The results were expressed as the mean number ( \pm standard deviation) of immunostained cells. The immunohistochemical assay was performed in explants exposed to $100 \mu \mathrm{M}$ of patulin and in control explants considering the results obtained in goblet cells assessment.

\subsection{Statistical analysis}

The experimental design used in the present study was entirely randomized with 24 repetitions for each treatment (each explant representing one repetition). Data were statistically analysed by the free software Action 2.3 (Campinas, SP, Brazil) using normality (Shapiro-Wilk's test) and homogeneity (Bartlett) tests. When these two assumptions were met the lesional score, the intestinal morphometry and the number of goblet cells were analysed by ANOVA followed by Tukey's test. Student's t-test was used to analyse the mean number of positive immunostained caspase- 3 cells. The $p$ value of $\leq$ 0.05 was considered significant.

\section{Results}

\subsection{Effects of patulin and ascladiol on histological and morphometric analysis}

After four hours of incubation, untreated explants (control group) presented mild villi atrophy and a mean histological score of 29.32. Explants exposed to PAT and ASC showed similar histological aspects in all concentrations. Additionally, some explants treated with PAT $(100 \mu \mathrm{M})$ also exhibited apical villi necrosis and lateral intercellular 
disruption (Fig.1). The mean histological score for the explants exposed to PAT (10, 30 and $100 \mu \mathrm{M}$ ) was $28.92,29.45$ and 29.50 and to ASC (30 and $100 \mu \mathrm{M})$ was 29.95 and 28.88, respectively. No statistical difference was observed in the lesional score between explants exposed to PAT and ASC compared to the control group.

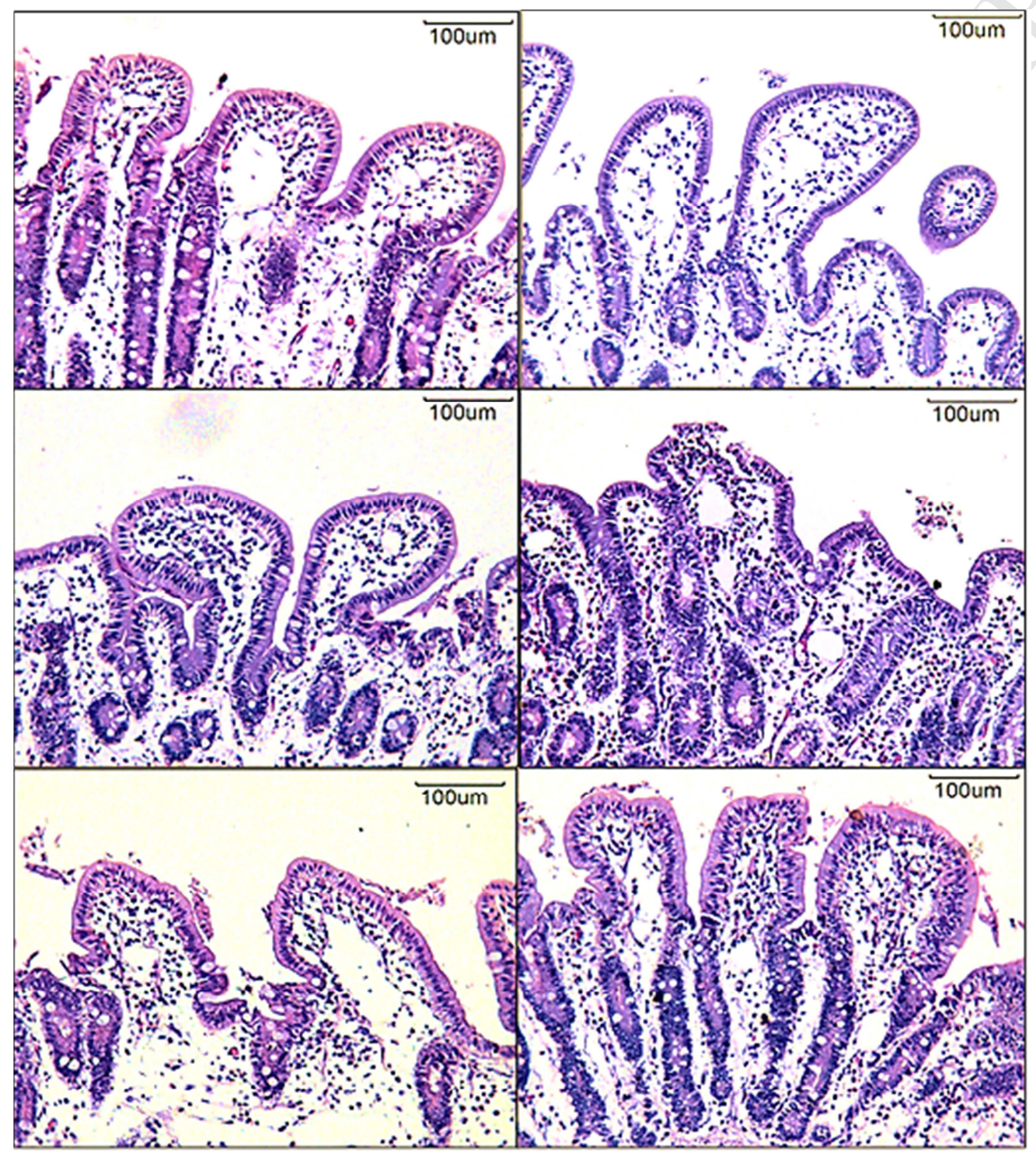

Figure 1. Histological aspects of jejunal explants exposed to patulin and ascladiol. Epithelial cells remained columnar in all treatments. Control group (A), Patulin $10 \mu \mathrm{M}$ (B), Patulin $30 \mu \mathrm{M}$ (C), Patulin $100 \mu \mathrm{M}$ with cellular disnuption (D), Ascladiol $30 \mu \mathrm{M}$ (E), Ascladiol $100 \mu \mathrm{M}$ (F). Haematoxylineosin, Bar $100 \mu \mathrm{m}$. 
Mean villi height was assessed in explants exposed to different concentrations of PAT and ASC, however no significant difference was observed when compared to control group. The control group showed mean villi height of $155.62 \pm 8.43 \mu \mathrm{m}$, while explants exposed to PAT $(10,30$ and $100 \mu \mathrm{M})$ and ASC (30 and $100 \mu \mathrm{M})$ showed mean villi height of $154.16 \pm 11.63 \mu \mathrm{m}, 147.43 \pm 13.18 \mu \mathrm{m}, 148.02 \pm 10.66 \mu \mathrm{m}, 148.55 \pm 6.48$ and $149.75 \pm 6.16 \mu \mathrm{m}$, respectively.

\subsection{Effects of patulin and ascladiol on goblets cells density}

The number of goblet cells in explants treated with PAT $100 \mu \mathrm{M}$ were significantly lower in villus $(p=0.05)$ and crypts $(p=0.03)$ comparing to the control group. Explants treated with $10 \mu \mathrm{M}$ and $30 \mu \mathrm{M}$ PAT and ASC remained statistically similar to control group (Fig.2)

\subsection{Effects of patulin on apoptosis index}

In order to evaluate a potential role of apoptosis in the decreased number of goblet cells an immunohistochemical assay was performed in jejunal explants. Considering that only the explants exposed to $100 \mu \mathrm{M}$ of PAT showed a significant difference in this parameter compared to the control group, the immunohistochemical expression of CCasp3 was achieved in these two groups. A significant increase in the number of immunostained cells to CCasp3 was observed in the villi $(6.47 \pm 1.77)$ and the crypts $(109.75 \pm 14.30)$ of explants exposed to $100 \mu \mathrm{M}$ of PAT when compared to the control group (2.56 \pm 0.53 for villi, $p=0.05 ; 46.26 \pm 11.02$ for crypts, $p=0.0089)$. 


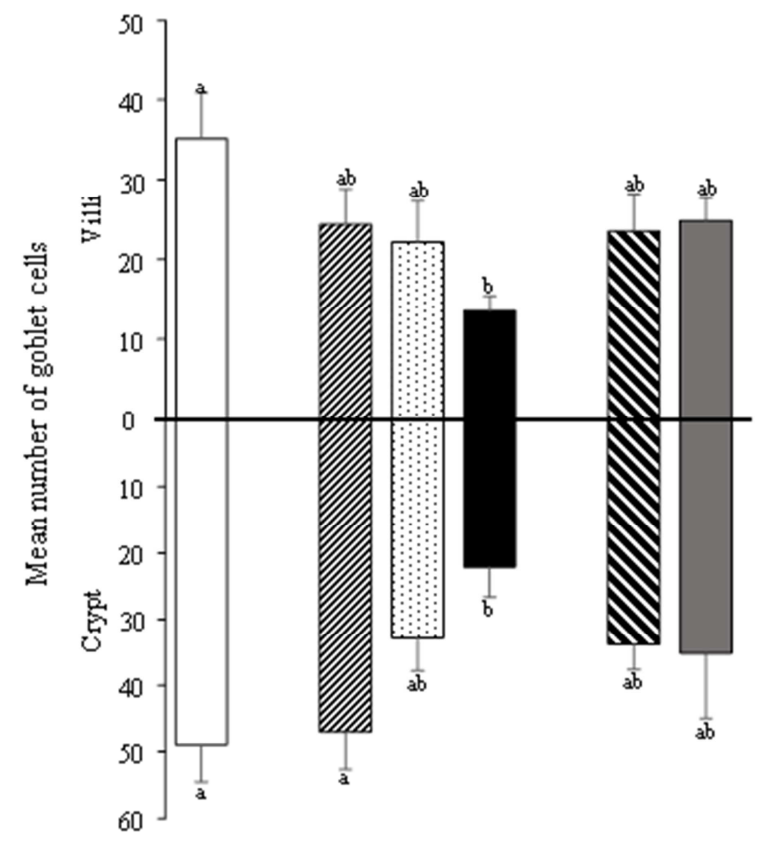

Figure 2. Mean goblet cell density on villi and cripts of explants exposed to control treatment (ם), PAT to $10 \mu \mathrm{M}(\mathbb{\square})$, PAT to $30 \mu \mathrm{M}$ (国), PAT to $100 \mu \mathrm{M}(\mathbf{m})$, ASC to $30 \mu \mathrm{M}(\mathbf{\Delta})$ and ASC to $100 \mu \mathrm{M}(\square)$. Values are mean \pm SD represented by vertical bars. a,b Mean values with unlike letters were significantly different $(p \leq 0.05)$. Tukey's test. $(p \leq 0.05)$.

\section{Discussion}

In the present study an alternative model to evaluate intestinal mucosal toxicity of PAT and ASC was used, based in previous studies (Pierron et al., 2015) where jejunal explants from pigs proved to be a reliable model to investigate the effects of food and feed contaminants, especially regarding the relevance of pig model-species compared to humans (Helke and Swindle, 2013). The doses of patulin used in this study were chosen to include the lowest observed adverse effect level (LOAEL) for chronic study in rats and a three and ten-fold higher dose (Becci et al., 1981). Levels of patulin in natural contaminations most frequently 
are below the maximum permitted level $(50 \mu \mathrm{g} / \mathrm{kg}$ ) (Harris et al., 2009), however occasionally high levels of PAT (until $44,572 \mu \mathrm{g} / \mathrm{kg}$ ) were reported (Piemontese et al., 2005). Alternatively, considering that no data about LOAEL was available for ascladiol similar doses were used.

In this study, the histological analysis revealed similar histological aspects in all explants exposed to PAT and ASC. Also, no significant difference in the lesional score or villi height was observed between explants exposed to different concentrations of these mycotoxins and the control group. Controversial results are reported in in vitro models. Caco-2 cell exposed to PAT $(100 \mu \mathrm{M})$ (Mahfoud et al., 2002; Mclaughlin et al., 2009) showed no change in apical, basolateral or basal sides, after 12 and 5 hours of incubation; moreover, epithelial monolayers remained confluent and expressed cell viability. On the other hand, exposure of Caco- 2 cells to concentration above $12 \mu \mathrm{M}$ of PAT induced a significant reduction in cell viability, mainly by changes in zonula occludens-1 levels (Assuncao et al., 2016). In addition, changes in transepithelial electric resistance (TEER) were also reported in intestinal cell lines Caco 2-14 and HT-29-D4 exposed to PAT (50 to $90 \mu \mathrm{M})$. The value of TEER is considered a good parameter for the protein cell junction organization and for the paracellular permeability (Mahfoud et al., 2002; Mohan et al., 2012; Assuncao et al., 2016). Altogether, literature data provide evidence of differences in toxicity according to cell type and patulin concentration, however, there is no previous study assessing the effects of ascladiol on intestinal tissue.

It is interesting to note that although no significant difference was observed in the lesional score between the mycotoxin-exposed groups and control explants, histological analysis revealed a mild enterocyte cell-cell contact disruption in jejunal explants treated with $100 \mu \mathrm{M}$ of PAT. This change suggests that high levels of PAT induce a loss of tissue 
integrity and may be related to alterations in the expression of TJs proteins (Katsuyama et al., 2014; Assuncao et al., 2016). The toxicity of PAT is thought to be due to the impairment of the intestinal barrier caused by the destruction of TJs in the epithelial cell layer (Assuncao et al., 2016) induced by ROS generation (Ferrer et al., 2009; Kawauchiya et al., 2011; Boussabbeh et al., 2015) and activation of apoptosis signaling (Wu et al., 2008; Boussabbeh et al., 2015; Zhang et al., 2015). These two proposed mechanisms are associated with the electrophilic properties of the conjugated double bond system, and include covalent inactivation of antioxidants and proteins (Fliege e Metzler, 2000).

Mucin synthesis and secretion play an important role as a physical barrier (highly glycosylated proteins) on intestinal mucosa (Pelaseyed et al., 2014). Changes in this dynamic may facilitate pathogen invasion and loss of tissue homeostasis. In this study a significant decrease (two fold) in goblet cells density was observed in explants exposed to high levels of PAT $(100 \mu \mathrm{M})$, both on villus and crypt region. Furthermore, a significant increase in cell apoptosis ( 2.5 fold) was observed in explants exposed to $100 \mu \mathrm{M}$ of PAT. Taken together, these results suggest that high levels of PAT induce a reduction in the number of goblet cells by an apoptotic pathway. Apoptosis induced by a ROS-dependent mechanism has been previously described in human intestinal and kidney cells exposed to PAT. Specifically, PAT induces both an endoplasmic reticulum stress and a drop in mitochondrial membrane potential leading to activation of the caspase pathway (Boussabbeh et al., 2015; Zhang et al., 2015). In addition, a decrease in the expression of mucin-related genes was reported in explants exposed to deoxynivalenol resulting in a reduction in the synthesis of mucin (Pinton et al., 2015). To the best of author's knowledge it is the first report to evaluate goblet cell density and apoptosis induced by patulin using 
the explant model; however the effects of PAT and ASC in mucin-related genes remain to be investigated.

Scientific data suggest that there is a wide variation in the results obtained among cell lines, time of exposure and concentration of toxins. Given the potentially high concentration of PAT in spoilt food products (Oroian et al., 2014; Van De Perre et al., 2014) and the high intestinal bioaccessibility of patulin (González-Arias et al., 2013) it is important to develop a database with results that will enable an understanding of the effects of this mycotoxin on the structure and function of the intestinal mucosa. Also, considering the potential use of microorganisms as biocontrol agents to reduce patulin contamination it is necessary to evaluate the toxicological effects of metabolites as ascladiol. Our results also demonstrated, for the first time, that ascladiol induced no toxic effects on the intestinal tissue.

\section{Acknowledgments}

LM and APFRLB are supported by a CNPq fellowship. JG is supported by a Capes/Fundação Araucária fellowship. This work was supported in part by the project CASDAR AAP RT $2015 \mathrm{~N}^{\circ} 1523$.

\section{Conflict of interest}

The authors declare no conflict of interest.

\section{References}

Al-Hazmi, M.A., 2014. Patulin in apple juice and its risk assessments on albino mice. Toxicol Ind Health, 30, 534-545. 
Appell, M.; Dombrink-Kurtzman, M. A.; Kendra, D. F., 2009. Comparative study of patulin, ascladiol, and neopatulin by density functional theory. J Molec Struct: Theochem, 894, 23-31.

Assuncao, R. et al., 2016. Characterization of in vitro effects of patulin on intestinal epithelial and immune cells. Toxicol Lett, 250-251, 47-56.

Barhoumi, R.; Burghardt, R. C., 1996. Kinetic analysis of the chronology of patulin- and gossypol-induced cytotoxicity in vitro. Fundam Appl Toxicol, 30, 290-297.

Basso, K.; Gomes, F.; Bracarense, A. P., 2013. Deoxynivanelol and fumonisin, alone or in combination, induce changes on intestinal junction complexes and in E-cadherin expression. Toxins (Basel), 5, 2341-2352.

Becci, P. J. et al., 1981. Long-term carcinogenicity and toxicity studies of patulin in the rat. J. Appl Toxicol, 1, 256-261.

Beretta, B. et al., 2000. Patulin in apple-based foods: occurrence and safety evaluation. Food Addit Contam, 17, 399-406.

Boussabbeh, M. et al., 2015. Patulin induces apoptosis through ROS-mediated endoplasmic reticulum stress pathway. Toxicol Sci, 144, 328-337.

Castoria, R. et al., 2011. Conversion of the mycotoxin patulin to the less toxic desoxypatulinic acid by the biocontrol yeast Rhodosporidium kratochvilovae strain LS11. J Agric Food Chem, 59, 11571-11578.

Commission of the European Communities, 2006. Commission Regulation (EC) No. 401/2006.

Ciegler, A.; Beckwith, A. C.; Jackson, L. K., 1976. Teratogenicity of patulin and patulin adducts formed with cysteine. Appl Environ Microbiol, 31, 664-667.

Cheat, S. et al., 2015. Nivalenol has a greater impact than deoxynivalenol on pig jejunum mucosa in vitro on explants and in vivo on intestinal loops. Toxins (Basel), 7, 1945-1961.

De Melo, F. T. et al., 2012. DNA damage in organs of mice treated acutely with patulin, a known mycotoxin. Food Chem Toxicol, 50, 3548-3555.

Ferrer, E. et al., 2009. Reactive oxygen species induced by beauvericin, patulin and zearalenone in CHO-K1 cells. Toxicol In Vitro, 23, 1504-1509.

Ferrer, M. et al., 2015. Influence of prebiotics, probiotics and protein ingredients on mycotoxin bioaccessibility. Food Funct, 6, 987-994.

Fliege, R.; Metzler, M., 2000. Electrophilic properties of patulin. $\mathrm{N}$-acetylcysteine and glutathione adducts. Chem Res Toxicol, 13, 373-81.

Food and Agriculture Organization, 2004. Worldwide regulations for mycotoxins in food and feed in 2003. Food and Nutrition Paper 81. Food and Agriculture Organization of the United Nations, Rome, Italy. 
Gc, L. L. et al., 1998. Immunological evaluation of the mycotoxin patulin in female B6C3F1 mice. Food Chem Toxicol, 36, 1107-1115.

Glaser, N.; Stopper, H., 2012. Patulin: Mechanism of genotoxicity. Food Chem Toxicol, $50,1796-801$.

Gonzalez-Arias, C.A. et al., 2013. Mycotoxin bioaccessibility/absorption assessment using in vitro digestion models: a review. World Mycotoxin J, 6, 167-184.

Harris, K.L., Bobe, G., Bourquin, L.D., 2009. Patulin surveillance in apple cider and juice marketed in Michigan. J Food Prot, 72, 1255-1261.

Hawar, S. et al., 2013. Biotransformation of patulin to hydroascladiol by Lactobacillus plantarum. Food Control 34, 502-508.

Helke, K.L., Swindle, M.M., 2013. Animal models of toxicology testing: the role of pigs. Expert Opin Drug Metab Toxicol, 9, 127-139.

Ianiri, G., Idnurm, A., Castoria, R., 2016. Transcriptomic responses of the basidiomycete yeast Sporobolomyces sp. to the mycotoxin patulin. BMC Genomics, 17, 210.

Katsuyama, A. et al., 2014. The mycotoxin patulin decreases expression of densityenhanced phosphatase-1 by down-regulating PPARgamma in human colon cancer cells. Tohoku J Exp Med, 233, 265-274.

Kawauchiya, T. et al., 2011. Correlation between the destruction of tight junction by patulin treatment and increase of phosphorylation of ZO-1 in Caco-2 human colon cancer cells. Toxicol Lett, 205, 196-202.

Kolf-Clauw, M. et al., 2009. Development of a pig jejunal explant culture for studying the gastrointestinal toxicity of the mycotoxin deoxynivalenol: histopathological analysis. Toxicol In Vitro, 23, 1580-1584.

Kwon, O. et al., 2012. Patulin induces colorectal cancer cells apoptosis through EGR-1 dependent ATF3 up-regulation. Cell Signal, 24, 943-950.

Liu, B. H. et al., 2007. Induction of oxidative stress response by the mycotoxin patulin in mammalian cells. Toxicol Sci, 95, 340-347.

Lopez-Diaz, T. M.; Flannigan, B., 1997. Production of patulin and cytochalasin E by Aspergillus clavatus during malting of barley and wheat. Int J Food Microbiol, 35, 129136.

Lopez-Diaz, T. M. et al., 1996. Mycotoxins in two Spanish cheese varieties. Int J Food Microbiol, 30, 391-395.

Lugauskas, A.; Repeckiene, J.; Novosinskas, H., 2005. Micromycetes, producers of toxins, detected on stored vegetables. Ann Agric Environ Med, 12, 253-260. 
Mahfoud, R. et al., 2002. The mycotoxin patulin alters the barrier function of the intestinal epithelium: mechanism of action of the toxin and protective effects of glutathione. Toxicol Appl Pharmacol, 181, 209-218.

Mckinley, E. R.; Carlton, W. W., 1980. Patulin mycotoxicosis in Swiss ICR mice. Food Cosmet Toxicol, 18, 181-187.

McLaughlin, J. et al., 2009. The mycotoxin patulin, modulates tight junctions in Caco-2 cells. Toxicol In Vitro, 23, 83-89.

Mohan, H. M. et al., 2012. The mycotoxin patulin increases colonic epithelial permeability in vitro. Food Chem Toxicol, 50, 4097-4102.

Oroian, M.; Amariei, S.; Gutt, G., 2014. Patulin in apple juices from the Romanian market. Food Addit Contam Part B Surveill, 7, 147-150.

Pelaseyed, T. et al., 2014. The mucus and mucins of the goblet cells and enterocytes provide the first defense line of the gastrointestinal tract and interact with the immune system. Immunol Rev, 260, 8-20.

Piemontese, L.; Solfrizzo, M.; Visconti, A., 2005. Occurrence of patulin in conventional and organic fruit products in Italy and subsequent exposure assessment. Food Addit Contam, 22, 437-442.

Pierron, A. et al., 2016. Intestinal toxicity of the masked mycotoxin deoxynivalenol-3- $\beta-\mathrm{d}-$ glucoside. Arch Toxicol, doi 10.1007/s00204-015-1592-8.

Pillay, Y. et al., 2015. Patulin triggers NRF2-mediated survival mechanisms in kidney cells. Toxicon, 99, 1-5.

Pinton, P. et al., 2015. Deoxynivalenol inhibits the expression by goblet cells of intestinal mucins through a PKR and MAP kinase dependent repression of the resistin-like molecule beta. Mol Nutr Food Res, 59, 1076-1087.

Puel, O.; Galtier, P.; Oswald, I. P., 2010. Biosynthesis and toxicological effects of patulin. Toxins (Basel), 2, 613-631.

Rahimi, E., Rezapoor Jeiran, M., 2015. Patulin and its dietary intake by fruit juice consumption in Iran. Food Addit Contam Part B Surveill, 8, 40-43.

Raiola, A. et al., 2012. Study of thermal resistance and in vitro bioaccessibility of patulin from artificially contaminated apple products. Food Chem Toxicol, 50, 3068-3072.

Ricelli, A. et al., 2007. Biotransformation of patulin by Gluconobacter oxydans. Appl Environ Microbiol, 73, 785-792.

Riley, R. T.; Showker, J. L., 1991. The mechanism of patulin's cytotoxicity and the antioxidant activity of indole tetramic acids. Toxicol Appl Pharmacol, 109, 108-126. 
Saxena, N. et al., 2008. Patulin in apple juices: Incidence and likely intake in an Indian population. Food Addit Contam Part B Surveill, 1, 140-146.

Saxena, N. et al., 2009. Patulin causes DNA damage leading to cell cycle arrest and apoptosis through modulation of Bax, $\mathrm{p}(53)$ and $\mathrm{p}(21 / \mathrm{WAF} 1)$ proteins in skin of mice. Toxicol Appl Pharmacol, 234, 192-201.

Schumacher, D. M.; Metzler, M.; Lehmann, L., 2005. Mutagenicity of the mycotoxin patulin in cultured Chinese hamster V79 cells, and its modulation by intracellular glutathione. Arch Toxicol, 79, 110-121.

Shao, S.; Zhou, T.; Mcgarvey, B. D., 2012. Comparative metabolomic analysis of Saccharomyces cerevisiae during the degradation of patulin using gas chromatographymass spectrometry. Appl Microbiol Biotechnol, 94, 789-797.

Silva, E.O. et al., 2014. Phytic acid decreases deoxynivalenol and fumonisinB1-induced changes on swine jejunal explants. Toxicol Reports, 1, 284-292.

Speijers, G. J.; Franken, M. A.; Van Leeuwen, F. X., 1988. Subacute toxicity study of patulin in the rat: effects on the kidney and the gastro-intestinal tract. Food Chem Toxicol, $26,23-30$.

Suzuki, T., et al., 1971. A new mycotoxin produced by Aspergillus clavatus. Chem. Pharm. Bull. (Tokyo), 19, 1786-8.

Suzuki, T.; Iwahashi, Y., 2011. Gene expression profiles of yeast Saccharomyces cerevisiae sod1 caused by patulin toxicity and evaluation of recovery potential of ascorbic acid. $\mathbf{J}$ Agric Food Chem, 59, 7145-7154.

Tannous J., et al., 2016. Patulin-transformation products and last intermediates in its biosynthetic pathway, E and Z-asladiol, are not toxic for human cells. Arch Toxicol. Under revision.

Van de Perre, E. et al., 2014. Screening for the presence of patulin in molded fresh produce and evaluation of its stability in the production of tomato products. J Agric Food Chem, 62, 304-309.

$\mathrm{Wu}, \mathrm{T}$. S. et al., 2008. Mechanism of patulin-induced apoptosis in human leukemia cells (HL-60). Toxicol Lett, 183, 105-111.

Yang, J. et al., 2014. Natural occurrence, analysis, and prevention of mycotoxins in fruits and their processed products. Crit Rev Food Sci Nutr, 54, 64-83.

Zhang, B. et al., 2015. Oxidative stress is involved in Patulin induced apoptosis in HEK293 cells. Toxicon, 94, 1-7.

Zhou, S. M. et al., 2009. Patulin-induced genotoxicity and modulation of glutathione in HepG2 cells. Toxicon, 53, 584-586. 


\section{Table legends}

Table 1 - Criteria used to establish the lesional score - endpoints used and severity factors.

\section{Figure legends}

Figure 1 - Histological aspects of jejunal explants exposed to patulin and ascladiol. Epithelial cells remained columnar in all treatments. Control group (A), Patulin $10 \mu \mathrm{M}(\mathrm{B})$, Patulin $30 \mu \mathrm{M}(\mathrm{C})$, Patulin $100 \mu \mathrm{M}$ with cellular disruption (D), Ascladiol $30 \mu \mathrm{M}(\mathrm{E})$, Ascladiol $100 \mu \mathrm{M}$ (F). Haematoxylin-eosin (HE), Bar $100 \mu \mathrm{m}$.

Figure 2. Mean goblet cell density on villi and cripts of explants exposed to control treatment (口), PAT to $10 \mu \mathrm{M}$ (ש), PAT to $30 \mu \mathrm{M}$ (䀳), PAT to $100 \mu \mathrm{M}(\mathbf{a})$, ASC to $30 \mu \mathrm{M}$ (v) and ASC to $100 \mu \mathrm{M}(\square)$. Values are mean \pm SD represented by vertical bars. a,b Mean values with unlike letters were significantly different $(p \leq 0.05)$. Tukey's test. $(p \leq 0.05)$. 


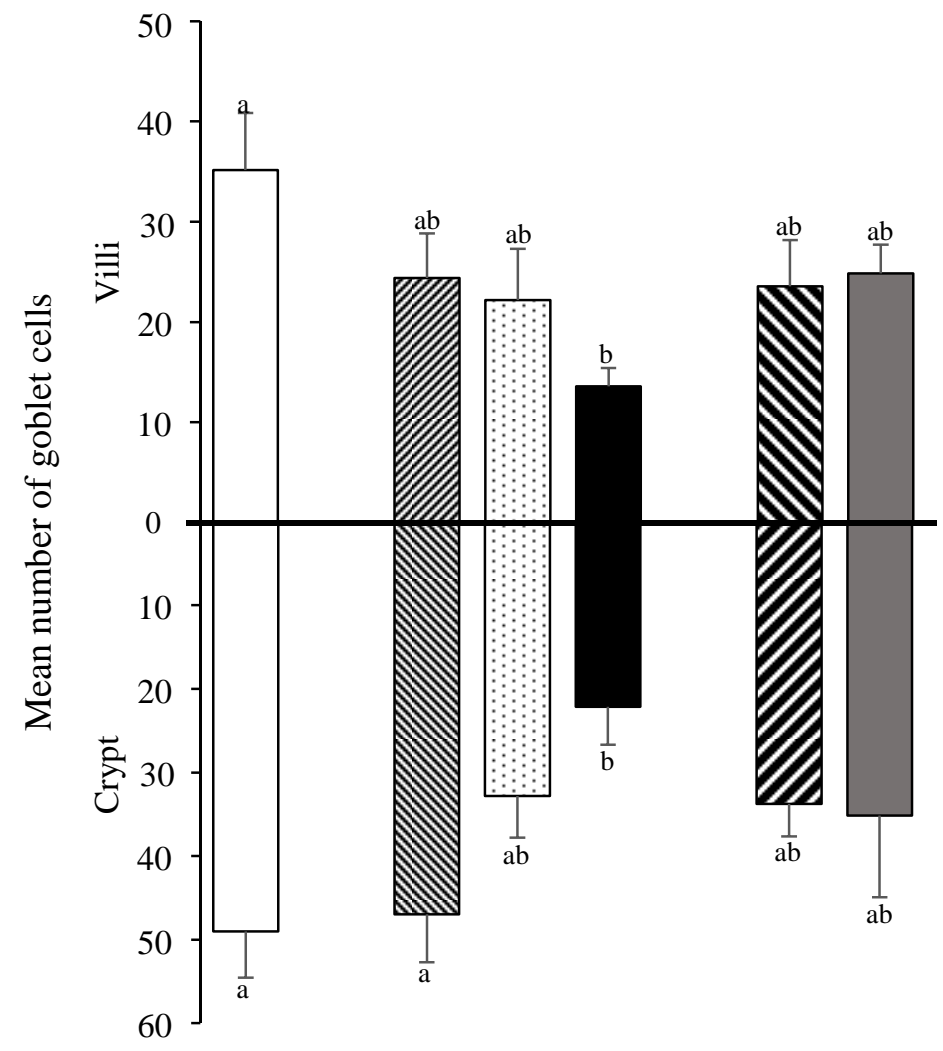

Figure 2. Mean goblet cell density on villi and cripts of explants exposed to control treatment ( $\square$ ), PAT to $10 \mu \mathrm{M}(\mathbf{z})$, PAT to $30 \mu \mathrm{M}$ (国), PAT to $100 \mu \mathrm{M}(\mathbf{\square})$, ASC to $30 \mu \mathrm{M}(\mathbf{v})$ and ASC to $100 \mu \mathrm{M}(\square)$. Values are mean \pm SD represented by vertical bars. a,b Mean values with unlike letters were significantly different $(p \leq 0.05)$. Tukey's test. $(p \leq 0.05)$. 
Highlights

- Patulin induces mild toxic effects on intestinal tissue.

- Ascladiol induces no toxic effects on intestinal tissue.

- Biotransformation of patulin seems to be a reliable process of detoxification . 